\title{
Postgraduate part-time education in optical design for technical personnel in the Russian optical industry
}

Michael Khoroshev

Michael V. Khoroshev, "Postgraduate part-time education in optical design for technical personnel in the Russian optical industry," Proc. SPIE 3190, Fifth International Topical Meeting on Education and Training in Optics, (8 December 1997); doi: 10.1117/12.294400

Event: Fifth International Topical Meeting on Education and Training in Optics, 1997, Delft, Netherlands 
Postgraduate Part - time Education in Optical Design

for Technical Personnel in Russian Optical Industry

\author{
Mikhail U. Khoroshev
}

Moscow State University of Geodesy and Cartografy. Part-time Faculty, RUSSIA, 103064, Hoscow, Gorokhouski by-str.. 4

\title{
ABSTRACT
}

Traditionally two interconpletly training forms are used in Russian optical industry: a training at University and at the high technology optical plant laboratories. The curriculun adaptation for specific part-tine conditions is nade by assoiating of sinilar courses. intensiving of the methodic preparation, using of the highest qualification faculty's lectors. Spesial attention is given to a naster's skill development by the intensification of the practice part of each cours of studies. Since 1961 about 2300 diplona engineers in optical desing graduated MIIGAiK Part-tine Faculty. Anong then are chiefs of the large scientific groups,the authors of the newest electro-optical devices, the lecturers and professors at the profesional educating systen.

Keywords: part-time education, specific training methodic, individual corriculuns, student's laboratory devices 
In 1961 MIIGAiK Part-time Faculty started technical personnel training in the field of optical designing. And in 1965 there were first qualified graduates. This training is ained to elevating of the qualification level of the personnel working at the enterprises where the different optical-electronic equipnent is used. This equipent is rendered on every stage of technological process of nanufacturing of the goods. The solution of this problen requires integrating of two nutually supplementing forms of educational process. The first is the indoor classes of technical laboratories of the University ( about 25\% of the general volune corriculuns, and the second one is training at high technology laboratories of the plants and the Faculty's branch set up at the head optical plants such as Scientific Assotiation " GEOFIZIKa " and Russian Scientific Research Institute of Spaceship Designing ( nore $75 \%$ of the volune ones ).

The form of the indoor classes training is classical, just like the full-tine education. It includes lectures, seninars, and laboratory practice in general subjects such as Physics. Chenistry. Phylosofy. History and etc. The specific feature of part-tine conditions is that the quantity of hours for indoor classes in the University is strictly linited by 16 hours per week. Besides students are activly encouraged to study and work without assistance and this form denands both fron the students and lectures. That is why the Faculty during all the periods of its existing attracts only the highly qualified lectures with great pedagogical experience. The number of such high professional tutors is no less that $80 \%$ of all the Part-tine Faculty lecturers. The highest teaching experience is very inportant for our lecturers in or- 
der to adapt the training programes for part-tie student' psychology, which has considerable distinctions both in age and in initial technical level, and physiological fatigue and other factors..

The second stage of training (that is held on industrial plants) is characterised by attracting of the elite spesialist in the field of optical high technology. It is very important that one of the University' department is in charge for general methodics control of one of the discipline given by corriculuns and one of the highly qualified lecturers is to supervise the training course. As a result of such cooperation the developing engineering skills of the students is going really effectively within the nethodics of professional training. The heads of optical construction and counting departnents, highly qualified technologist, leading in different branches of optical industry, economics experts and final products testers are involved for lectures and laboratory practicing. Taking into account the listed conditions it is obviously that the training with the help of technical experts from plants is nore effective as a rule for students of Parttine Faculty, than the University' lecturers.

Taking into account the main task of the study without interruption of work is to increase the qualification of the students we pay special attention at the Part-tine Faculty to the developing of engineering skills by increasing the practical component of study disciplines. Besides the Part - tine corriculuns includes nore integrated subjects which are containing a few ordinary courses. The training of each students is based on individual approach and includes the indivi- 
dual plans of study both in the separate discipline and in the corriculuns itself. The considerable component of individual corriculums is oriented on the profound studying of those subjects which are necessary for student for his job. But this doesn't mean that he is free fron studying the theoretical aspect of these subjects. Many of such individual schedules are nade for creating and producing the certain nodels of the devices which will be used as appliances for laboratory works for other trainees in future. This is the way for a student to prove his ability to solve any engineering problems even if he's still in the process of training. Such approach gives the ability to control the general level of student's qualification according to the results on different stages of training. It allows also to check and correct the training schedule and to shorten it if possible.Students which are more active in practice in the process of training have as a rule really good results of there work and they are successfully promoted. Since 1961 two thousands two handreds eighty six diplona engineers in optical designing graduated MIIGAiK Part-tine Faculty. Sone of then becane after 5.8 years of the study at the University the Heads Manager of the Departments with 50 and nore staff nembers. For the last years the Faculty trained nany specialists which were at the nonent of their graduation the leaders of large plant shops, general plant services. and optical designing departments. Many of our graduates during the period of training have invented lots of workable optical-electronical devices. 